American Journal of Economics and Business Administration 4 (1): 59-64, 2012

ISSN 1945-5488

(C) 2012 Science Publications

\title{
A Comparison of the Business Environments of Two Emerging Economies
}

\author{
Celina Garcia and Zaida L. Martinez \\ Department of Management, St. Mary's University, \\ One Camino Santa Maria, San Antonio, Texas 78228, USA
}

\begin{abstract}
Problem statement: Brazil and Mexico, the two largest emerging economies of Latin America, have undergone significant transformation in the past decades providing unique business opportunities to international entrepreneurs. To take advantage of the business opportunities in these emerging markets, however, entrepreneurs need a basic understanding of the economic and regulatory developmental patterns that have characterized each country. Conclusion/Recommendations: This study provides a preliminary review of economic and regulatory factors affecting the business environments of Mexico and Brazil. Emphasis is given to the developmental path taken by each country in its economic liberalization and the implications of these differences for international entrepreneurs interested in pursuing business opportunities in these emerging markets.
\end{abstract}

Key words: Foreign direct investment, corruption, business legal environment

\section{INTRODUCTION}

An international entrepreneur, whether through exporting, licensing, or foreign direct investment, "creates wealth and employment that benefits individuals and nations" (Hisrich, 2009). Over the past 20 years, Brazil and Mexico have been seen as leaders in the emerging markets of Latin America and are seen as attractive for trade and foreign investment. Nonetheless, achieving success in emerging economies requires that international entrepreneurs constantly consider factors beyond their control such as "economics, politics, technology and culture" (Hisrich, 2009). For example, planning for a business in a foreign country requires knowledge of the "differences in levels of economic development; currency valuations; government regulations, banking, venture capital, marketing and distribution systems" (Hisrich, 2009). Furthermore, international entrepreneurs can accomplish their goals in spite of "newness and smallness by conducting themselves in appropriate manners prescribed and sanctioned by the institutional environment" of that country (Eunni, 2010).

The purpose of this study is to provide a preliminary review of economic and regulatory factors affecting the business environments of Mexico and Brazil. Emphasis is given to the developmental path taken by each country in its economic liberalization and the implications of these differences for international entrepreneurs interested in pursuing business opportunities in these emerging markets. Specifically, the study compares each country's economic development, business structures and the impact of corruption.

\section{Economic development patterns:}

Mexico: In the early 1990s Mexico was making headlines for embarking on reforms prescribed by the Washington Consensus, a series of guidelines encouraging liberalization of markets. However, in 1994 Mexico fell into a peso devaluation crisis that resulted in a significant decrease in its foreign exchange reserves. Loans from the IMF and the U.S. helped stabilize the Mexican peso. Also, the ratification of the North American Free Trade Agreement (NAFTA) in 1994 contributed to an increase in trade, mainly in relation to U.S. imports, which rose from 7-12\% since NAFTA was passed (CIA, 2011a). Over the past 5 years, global foreign direct investment net inflows into Mexico decreased significantly from 29.73 billion (USD) in 2007-15.33 billion in 2009 (WB, 2011). In 2010 FDI inflows rose and were estimated at 18.68 billion (WB, 2011). Mexico is currently ranked as the twelfth largest economy in the world by GDP (CIA, 2011b).

Since the implementation of NAFTA, Mexico has continued a policy of trade liberalization resulting in free trade agreements with over 50 countries (CIA, 2011a). In effect, more than 90\% of Mexico's trade takes place under free trade agreements (CIA, 2011a). More importantly, the opening of the Mexican economy to Foreign Direct Investment (FDI) was directly tied to Mexico's trade liberalization policies. Currently, there are few areas of the economy that are restricted to the state and Mexican nationals, most

Corresponding Author: Celina Garcia, Department of Management, St. Mary's University, One Camino Santa Maria San Antonio, Texas 78228, USA 
notably in the oil and energy sectors (BMIL, 2010). According to the Foreign Investment Law in Mexico, out of 704 business activities, 656 are open for $100 \%$ FDI (BMIL, 2010). The Mexican government is highly open to foreign investment, creating incentives and programs that support foreign investment in underdeveloped sectors and underdeveloped regions. In addition, about $95 \%$ of foreign investment transactions do not require government approval (USCS, 2011). Although Brazil has been receiving more FDI inflows than Mexico in recent years, Mexico is still viewed as being more receptive to foreign investment (The Economist, 2011).

Mexico's economy is characterized by contrasting because of its mixture of outmoded and advanced industries (CIA, 2011a). The most attractive sectors for FDI are manufacturing, trade activities and financial activities (USCS, 2011). Although Mexico offers an open economy for foreign investors, several crucial sectors can be described as being dominated by a few companies, inhibiting competition in these sectors. Examples of these sectors are telecommunications, electricity, television broadcasting, petroleum and cement sectors (USFCSUSDS, 2011).

The liberalization of trade and FDI has contributed to Mexico's economic growth (albeit slow growth compared to other Latin American countries); nonetheless, Mexico continues to exhibit high levels of poverty. According the Coneval, the Mexican government agency in charge of tracking changes in poverty, the number of people living in poverty (defined as living on 2,100 pesos or $\$ 150$ ) increased from 49 million to 52 million between 2008, 2010 (Uranga, 2011). Moreover, wages continue to be low with the daily minimum wage in 2011 ranging from 54.47 pesos (\$4.45)-57.46 pesos (\$4.69) depending on the region of the country (WMWR, 2011). Given the competition for foreign direct investment from other countries boasting low wages, such as China and India, a rise in Mexican wages is unlikely in the near future (BMIL, 2010).

Similar to many countries in Latin America, Mexico has an active and wide ranging informal economy. According to a study by the ILO in 2003, $41.8 \%$ of all jobs in Mexico were informal with $17.9 \%$ in the informal small business sector (Eunni, 2010). As in any nation, the informal economy undermines lawful business interaction since informal businesses are not complying with business regulation laws, such as taxes and labor laws. The inconsistent enforcement on the part of regulatory agencies allows informal businesses to sell pirated and "poor-quality goods at low prices undercutting the competitiveness of lawful firms" (Eunni, 2010). Moreover, Mexico has experienced complications arising from the connection of the informal sector with the drug trade (Eunni, 2010).
Brazil: The import substitution model that was used for economic development in Brazil in the 1980s focused on establishing domestic industries in order to limit dependence on foreign production. This model was not successful in transitioning Brazil into the new economic realities of globalization (Gallagher and Chudnovsky, 2009). However, the 1990s brought important reforms, including a reduction of state intervention in the economy, the liberalization of the flow of trade and capital and the privatization of state-owned companies (Gallagher and Chudnovsky, 2009). Furthermore, in 1994 Brazil introduced an economic stabilization plan called Plano Real in order to contain runaway inflation (Eunni, 2010).

Brazil has treaties prohibiting double taxation with twenty-four countries including, the Netherlands, France, Italy and Argentina (USFCSUSDS, 2011). However, it has no such treaty with the United States. Also, Brazil does not have a "bilateral investment treaty" with the United States (USFCSUSDS, 2011) although investments from U.S. companies are a significant part of the total FDI in Brazil, calculated at $\$ 56.7$ billion in 2009 (IMF, 2012).

During the mid-1990s, Brazil experienced an increase in FDI (Gallagher and Chudnovsky, 2009), a trend that has continued. Moreover, Brazil has taken center stage in Latin America as an attractive destination for foreign investment due to its rising middle class and growing domestic consumption (Newman et al., 2011). Compared to Mexico, Brazil has a larger economy (Kiernan, 2011) and is currently ranked as the ninth largest economy by GDP (CIA, 2011b). Furthermore, its economy has experienced significantly stronger growth in GDP per capita than Mexico, as indicated in Fig. 1.

Brazil is recognized for its well-developed agricultural, mining, manufacturing and service sectors and its ability to continue to "expand into world markets", including airplane manufacturing and hydroelectric power (CIA, 2011a). However, some sectors, such as non-cable television broadcasting and aviation, offer limited openness to foreign investment. In the broadcasting sector, companies are subject to regulations requiring that a minimum of $80 \%$ of programming have domestic origins (USFCSUSDS, 2011). In the aviation sector, the foreign ownership is restricted to $20 \%$ (USFCSUSDS, 2011).

The liberalization of Brazil's economy also had a positive impact on FDI. For example, the Brazilian government extends special tax benefits for investments in underdeveloped regions of the country (USFCSUSDS, 2011). An economy considered less open than Mexico, Brazil has more FDI inflows than Mexico in recent years (WB, 2011) and is currently the largest recipient of FDI in Latin America (USFCSUSDS, 2011). Figure 2 depicts a comparison of FDI inflows in Mexico and Brazil. 


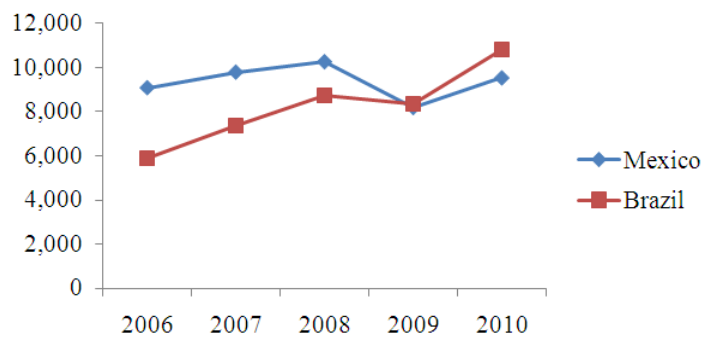

Fig. 1: GDP per Capita in Mexico and Brazil

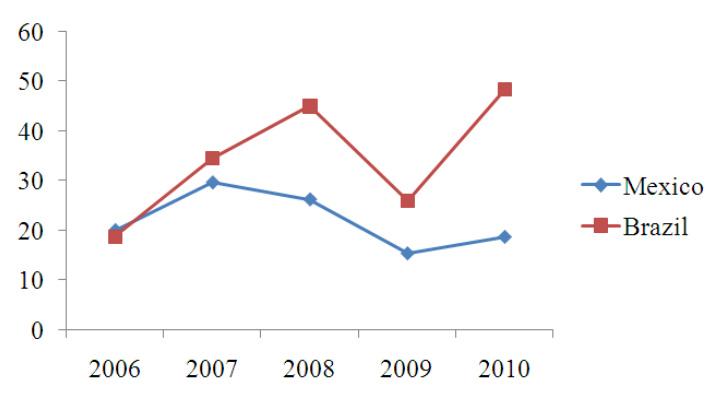

Fig. 2: Mexico and Brazil Foreign Direct Investment Inflows 2006-2010

Like Mexico, Brazil also has a poverty problem, with about 16 million people living in extreme poverty, defined as living on 70 reais or less (equivalent to $\$ 44$ a month) (BLSLMP, 2011). However, the government has developed programs, such as "Bolsa Familia", that have helped address the needs of the poor (BLSLMP, 2011; Rosenberg, 2011). Nonetheless, wages in Brazil are relatively low in comparison with other countries. For 2011, the minimum monthly wage was 510 reais $(\$ 320)$ (WMWR, 2011).

Brazil parallels Mexico with an active informal economy that undermines lawful business. In 2003, a study by the ILO reported that $44.6 \%$ of the jobs in Brazil are part of the informal economy, of which $14.3 \%$ are informal micro and small enterprises (Eunni, 2010).

Business structures: The legal framework of a country plays a crucial role in the regulation of the economy and businesses. As the business environments of Mexico and Brazil continue to evolve, modifications to the legal framework regarding business are highly likely in order to accommodate the changing global economy.

Mexico: In contrast to the United States and other countries with ties to the English system, the legal system in Mexico and Brazil is based on civil law, with roots in the Napoleonic law (Trujillo and Molloy, 2009). The main difference is that the law that is applied comes exclusively from the Constitution and codes (Trujillo and Molloy, 2009). This detail is important to note because a person who is conducting business in Mexico will encounter many federal laws and detailed codes that affect business operations (Trujillo and Molloy, 2009). In Mexico the legal framework affecting business organizations is primarily at the federal rather than the state level (Trujillo and Molloy, 2009). The General Corporation Law provides for the existence of six types of commercial organizations (Trujillo and Molloy, 2009). However, the most commonly used commercial organizations are the limited liability stock called "sociedad anónima" and the limited liability company known as "sociedad de responsabilidad limitada" (Trujillo and Molloy, 2009).

The limited liability stock or "sociedad anónima", which is the most widely used business structure in Mexico is estimated to represent $99 \%$ of the capital invested in Mexico (Trujillo and Molloy, 2009). Requirements for the establishment of a "sociedad anónima" include a minimum of two stockholders and a minimum share capital of at least 50,000 Mexican pesos (Trujillo and Molloy, 2009). The authorized capital for a sociedad anónima must be "paid or pledged" upon the incorporation (Trujillo and Molloy, 2009). The management of a "sociedad anonima" can comprise a sole administrator or a board of directors (Trujillo and Molloy, 2009).

The limited liability company or "sociedad de responsabilidad limitada" is "formed by members whose obligations are limited to the payment of their contributions to the capital" of the company (Trujillo and Molloy, 2009). As with "sociedades anónimas", the limited liability company must have a minimum of two members (Trujillo and Molloy, 2009) but not exceed fifty members (Trujillo and Molloy, 2009). In order to establish a limited liability company, there is a minimum capital requirement of 3,000 Mexican pesos (Trujillo and Molloy, 2009). In contrast to a "sociedad anónima", ownership interests are not represented by negotiable certificates. Ownership interests can be transferred only in specific cases approved by the General Corporation Law.

Brazil: As is the case in Mexico, the basic legal structure of Brazil is based on civil law with businesses having to comply with various civil codes (Centro de Estudos das Sociedades de Advogados, 2012). Brazil offers various methods of conducting business, including joint ventures, corporations and franchises. The most common procedure used by foreign investors for conducting business in Brazil is business formation. As in Mexico, the most popular business structures in Brazil are the limited liability company ("sociedade limitada") and the joint-stock company ("sociedade por ações"). 
A "sociedade por acoes " (joint-stock company) can be formed by public or private subscription of its shares(Centro de Estudos das Sociedades de Advogados, 2012). Both the "sociedade por acoes" and the "sociedade limitada" must have a minimum of two partners, whether individuals or legal entities (Centro de Estudos das Sociedades de Advogados, 2012). In a joint-stock company each shareholder is "liable only to the extent that the capital stock for which it has subscribed remains unpaid" and a minimum of $10 \%$ of the capital must be paid upon the incorporation (Centro de Estudos das Sociedades de Advogados, 2012). Contrary to Mexico, Brazil has no minimum corporate capital requirements for establishing either business structure (PricewaterhouseCoopers, 2001). Instead, the corporate capital may be divided among the partners according to the bylaws (PricewaterhouseCoopers, 2001).

Similar to the formation of a joint-stock corporation, a limited liability company requires a minimum of two partners, whether individuals or legal entities, who do not need to reside in Brazil (PricewaterhouseCoopers, 2001). Like the joint-stock corporation there is no minimum capital requirement for establishing a limited liability company (PricewaterhouseCoopers, 2001). A major distinction, however, is that in a limited liability company, the liability of each partner is limited to the amount of its contributions, but all partners are jointly liable for the total amount of the capital stock until it is fully paid (Centro de Estudos das Sociedades de Advogados, 2012). Also, the corporate capital can be divided into quotas and allocated to its partners in proportions according to the bylaws (PricewaterhouseCoopers, 2001). The management of a limited liability company may be appointed to either an individual or to a group of senior managers (Centro de Estudos das Sociedades de Advogados, 2012).

Mexico and Brazil share common features in their business structures within a similar legal framework. However, based on the World Bank 2011 rankings of 183 economies, Mexico is viewed as an economy where it is easier to do business in comparison to Brazil (WBG, 2011). Mexico has also been recognized as having a more liberal business environment as a result of recent reforms that make establishing and operating businesses easier and less time consuming (WBG, 2011). The rankings of Brazil and Mexico are listed in Table 1. A lower number in the rankings indicate greater ease of doing business.

When Mexico and Brazil are compared to other countries in Latin America and the Caribbean, Mexico ranks as the sixth best country for "Ease of Doing Business" compared to Brazil, which had a ranking of 26 out of the 32 countries included in the region (DB, 2011). Moreover, in the Doing Business 2011 report, Mexico was one of the Latin American countries that improved in a minimum of three categories for business reform (WBG, 2011).
Corruption: Although definitions of corruption vary, corruption is generally defined as "the improper use of resources, such as bribery, nepotism, extortion, use of privileged information, fraud and others for nonofficial purposes" (Halter et al., 2009). Perceptions of corruption can differ from actual corruption (Ionescu, 2011). The perception of corruption can undermine efforts to combat it by discouraging citizen participation, since the perceptions of corruption are linked to distrust of institutions on the part of the citizens (Ionescu, 2011). Both perceptions of corruption as well as actual incidents of corruption can be detrimental to a country's economic development (Halter et al., 2009) and present major challenges for doing business internationally.

Mexico and Brazil have a long history of corruption. In Mexico the perception of corruption is positively linked to the actual experience of corruption (Ionescu, 2011). For example, according to the Centro de Estudios Economicos Del Sector Privado, corruption in Mexico is common at the federal, state and local levels of government (BMIL, 2010). Moreover, the drug trade has exacerbated corruption in Mexico and has adversely affected business operations as drug cartels are known to extort businesses for protection from violence (Gray, 2010). The violence in affected areas of Mexico has also resulted in reduced traffic and revenues for tourist centered areas (Gray, 2010). Not surprisingly, Guerrero and Rodriguez-Oreggia noted that corruption has resulted in "transaction costs, uncertainty and lower productivity" in Mexico (cited in Ionescu, 2011).

Corruption in Brazil also presents challenges, since it is often viewed as part of business practice and a quick method of solving problems (Halter et al., 2009). Corruption comes in many forms including gifts, personal favors and the unauthorized trading of information for the benefit of individuals or business entities (Halter et al., 2009). Apart from the financial costs, corruption can have "high legal, social and ethical costs including a loss in reputation" and an atmosphere that institutionalizes corruption (Halter et al., 2009).

Table 1: World Bank Group Rankings of Economies, 2011 Economies are ranked on their ease of doing business, from 1-183. The rankings for all economies are benchmarked to June 2011 (WBG, 2011)

\begin{tabular}{lcc}
\hline & Brazil & Mexico \\
\hline Ease of Doing Business & 126 & 53 \\
Starting a Business & 120 & 75 \\
Registering Property & 114 & 140 \\
Getting Credit & 98 & 40 \\
Protecting Investors & 79 & 46 \\
Trading Across Borders & 121 & 59 \\
Enforcing Contracts & 118 & 81 \\
\hline Source: WBG (2011) Ranking of Economies
\end{tabular}


Table 2: Comparison of Mexico and Brazil of Factors Affecting Business. This table shows the percentage of responses that identified the following factors as most problematic

\begin{tabular}{ll}
\hline Mexico & Brazil \\
\hline The most problematic factors for doing business & The most problematic factors for doing business \\
Crime and theft-16.5 & Crime and theft-1.3 \\
Corruption- 15.2 & Corruption- 6.4 \\
Inefficient government bureaucracy-14.2 & Inefficient government bureaucracy-10.5 \\
Tax regulations-10.3 & Tax regulations-16.6 \\
Tax rates-5.0 & Tax rates- 19.3 \\
\hline
\end{tabular}

Source: WEF (2011) Global Competitiveness Report

The prevalence of corruption in the business sector is a factor to be considered when analyzing the stability of a country as it can be considered "an ordinary economic activity that arises in some institutional environments and becomes dangerous to democracy itself" (Halter et al., 2009). Since the "lack of transparency is a factor that promotes corruption", (Halter et al., 2009) coherency and consistency can make it easier for foreign investors to manage a business (Halter et al., 2009). In recent years, however, Brazil has stepped up its initiatives for combating corruption. Examples include the creation of the Transparency Portal, an online website where Brazilians can track the "financial execution of federal government programs" (OCG, 2009). Proposals have been presented to Congress too "reform the legal framework in this area" (UNODC, 2011).

Transparency International compiles a yearly index of perceived corruption in which countries are ranked at a level of $0-10$ with 0 signifying "highly corrupt" and 10 "very clean" TI, 2011. According to the Transparency International Corruption Perceptions Index for 2011, Mexico scored 3.0 TI, 2011 and had a ranking of 100 out of 183 countries, thus placing it in the bottom half of the countries ranked. In the Corruption Perceptions Index of 2011, Brazil fared better than Mexico with a score of 3.8 and a ranking of 73 out of 183 countries, thus falling in the upper half of the countries ranked.

The Global Competitiveness Report asked respondents to select the five most problematic factors for doing business out of a list of 15 factors and to rank them between 1(most problematic) and 5(least problematic) (WEF, 2011). In the Global Competitiveness Report of 2011, Mexico's top two most problematic factors for doing business were identified to be crime and corruption (WEF, 2011). Brazil's most problematic factor for doing business was viewed to be tax rates with $19.3 \%$ of responses identifying it so (WEF, 2011). Only $6.4 \%$ of responses stated corruption as most problematic in Brazil (WEF, 2011). This contrasts Mexico's $15.2 \%$ of responses that identify corruption as most problematic (WEF, 2011). Based on the results published in this report, Brazil may be perceived as less corrupt than Mexico. Table 2 compares Mexico and Brazil and states the percentage of responses that identify various factors as most problematic in doing business.

\section{CONCLUSION}

The economies of Mexico and Brazil share the same popular business structures and a similar legal structure. According to what is published by the World Bank and other reliable sources, there are more hurdles for the entrepreneur when establishing a company in Brazil than in Mexico, but there is a higher perception of corruption in Mexico than Brazil. The types of reform undertaken in the two countries have most likely contributed to these differences. These changes may suggest that the more bureaucratic government system present in Brazil is more favorable to businesses than the opener and liberal business environment in Mexico, possibly because it reduces uncertainty. Thus, entrepreneurs can be misinformed by relying on rankings and other statistical information and would, therefore, benefit from more specific information on the intricacies of the bureaucratic structure of the government and how it affects businesses. Thus, additional research is needed for assisting international entrepreneurs when comparing potential countries for future business ventures. Governments would also benefit from investigating this factor further since it can influence future business development in their country.

\section{REFERENCES}

BLSLMP, 2011. BBC New Latin America and Caribbean. Brazil Launches Scheme to Lift Millions Out of Poverty.

BMIL, 2010. Business environment. Business Monitor International Ltd., Business Forecast Report, Mexico. www.businessmonitor.com

Centro de Estudos das Sociedades de Advogados, 2012. Legal Guide for Foreign Investors in Brazil. Brasil Global Net.

CIA, 2011a. Brazil. CIA the World Factbook.

CIA, 2011b. Country Comparison: GDP. World Factbook, CIA, World Factbook Publications.

DB, 2011. Doing business in a more transparent world. International Finance Corporation, Doing Business, The World Bank.

Eunni, R.V., 2010. Institutional environments for entrepreneurship in emerging economies: Brazil Vs. Mexico. World J. Manage. 
Gallagher, K. and D. Chudnovsky, 2009. Rethinking Foreign Investment for Sustainable Development: Lessons from Latin America. 1st Edn., Anthem Press, New York, ISBN-10: 1843313162, pp: 291.

Gray, C., 2010. Hidden cost of the war on drugs. The Stanford Progressive.

Halter, M.V., M.C.D. Arruda and R.B. Halter, 2009. Transparency to reduce corruption? J. Bus. Ethics, 84: 373-385. DOI: 10.1007/s10551-0090198-6

Hisrich, R.D., 2009. International Entrepreneurship: Starting, Developing and Managing a Global Venture. 1st Edn., SAGE Publications, Inc., Los Angeles, ISBN-10: 1412957982, pp: 623.

IMF, 2012. World economic outlook. International Monetary Fund.

Ionescu, L., 2011. Mexico's pervasive culture of corruption. Econ. Manage. Finan. Markets, 6: 182-187.

Kiernan, P., 2011. Brazil's Per-Capita Income Surpassed Mexico In 2010. Wall Street J.

Newman, S., C. Rickert and R.D. Schaap, 2011. Investing in the post-recession world. Harvard Bus. Rev.

OCG, 2009. Transparency portal. Office of the Comptroller General.

PricewaterhouseCoopers, 2001. Doing Business and Investing in Brazil. 1st Edn., PrcewaterhouseCoppers, New York, Sao Paulo, pp: 325. Auditores Independentes.
Rosenberg, T., 2011. To beat back poverty, pay the poor. The New York Times Company.

The Economist, 2011. Mexico's economy Making the desert bloom. Economist.

Trujillo, J.M. and J.F. Molloy, 2009. A Guide to Incorporating a Business in Mexico. 1st Edn., National Law Center for Inter-American Free Trade, Tucson, pp: 159.

UNODC, 2011. Brazil and the Southern Cone. United Nations Office on Drugs and Crime.

Uranga, R., 2011. Growing poverty looms for next Mexican president. Chicago Tribune News.

USCS, 2011. Mexico commercial guide. Country Commercial Guide, US Commercial Service.

USFCSUSDS, 2011. Doing Business in Brazil. Country Commercial Guide for U.S. Companies, U.S. and Foreign Commercial Service and U.S. Department of State.

WB, 2011. Foreign direct investment, net inflows (BoP, current US\$). The World Bank Group.

WBG, 2011. Economy Rankings. Doing Business, The World Bank Group.

WEF, 2011. The global competitiveness report 20112012. World Economic Forum, Geneva Switzerland.

WMWR, 2011. Brazil minimum wage. International Minimum Wage Rates, World Minimum Wage Resource. 